\title{
北海道帝国大学の営縉組織の沿革と建築技術者について \\ THE HISTORY AND THE STAFFS OF THE ARCHITECTURAL SECTION OF HOKKAIDO IMPERIAL UNIVERSITY
}

\author{
池上重 康*, 越野 武**, 角 '幸博*** \\ Shigeyasu IKEGAMI, Takeshi KOSHINO and Yukihiro KADO
}

\begin{abstract}
We ascertain the history and the staffs of the architectural section of Hokkaido Imperial University between 1918 and 1940, and tried defining it as a part of the official architectural organizations. There was an aspect of the control by the Education Ministry, that only the men who had had some experience in the architectural section of the Education Ministry were appointed to the engineers or the assistant engineers in the period from 1918 to 1921. With the enactment of 'Law of University' and 'Law of Higher School' in 1918, however, we can say that, the improvements of the facilities and the cultivation of the architects along with the progress of higher education enabled the architectural section of the University to employ its staffs and design its facilities independently.
\end{abstract}

\section{Keywords : Hokkaido Imperial University, architects'and engineerings' organization, architectural section of Education Ministry, engineer, part-time engineer, assistant engineer}

北海道帝国大学、営繕組織、文部大臣官房建筑課、技師、嘱託、技手

\section{1. はじめに}

日本における帝国大学 (以下、帝大と略) の営繶組織とその技術者 および建築活動については、先に宮本雅明による『日本の大学キャ ンパス成立史』1)があり、明治期の文部省営繥組織の建築技術者と その活動をまとめている。ここで宮本は、大正後半以降は帝大にお いて学部が多数新設され、一方で各帝大の営繒組織 2 は文部省中央 からの独立化が進行したと指摘している。しかし、その独立化の具 体的な内容は示されていない。

大正 7 年 12 月には「大学令」および「高等学校令」が公布され、 全国高等教育機関の創設および桩張政策が打ち出された。ごれに先 んじて同年 4 月に独立帝大 (従前は東北帝大農科大学) へと昇格した 北海道帝大では、新設となった医学部と工学部の校舎建設に向け て、独自の営繙組織が設置され、キャンパス施設の建築と営繥ス タッフの充赛が並行して行なわれた。こうした背景もあって北海道 帝大は、大正後半以降の文部省中央からの独立を具体的に一帝大の 営縡組織の構成と職務内容についてうかがうことができる格好の事 例といえる。

他の帝大においては、京都帝大に関する研究 ${ }^{3)}$ のほかに、東北帝 大と九州帝大についての報告 ${ }^{4)}$ があるが、いずれも技師や技手など 中心的なスタッフの来厢を明らかにするか、建築活動に重点をお
き、設計者や建築的特徽を考察するに留まっている。特に大正後半 以降の文部省中央からの独立化を、具体的に一帝大を対象に営繒組 織の治革および建案活動について考察した詳細な報告はまだない。

ところで宮本は前揭書において、北海道帝国大学に関して、その 前身である札幌農学校 (以下、農学校と略) および東北帝国大学農科 大学 (以下、農科大学と略) 時代を対象に、文部技師として大臣官房 建築課札幌出張所に赴いた中條精一郎（1868～1936）と新山平四郎 (1869〜 ?)の 2 名を中心に考察しているが、北海道帝大として独立 以降は断片的な扱いに留まっている5)。また、菅野誠は『白本の学 校建築』6)の中で、北海道帝大時代の建策のうち工学部本館を取り 上げ、その設計者について考察しているが、これ以外の建築および その設計者についでは言及していない。

北海道内の官庁営繥組織に関するこれまでの研究においても、開 拓使や北海道庁、道内各自治体を中心に、職員の移動といった形で 北海道帝大 (およびその前身) の営繽組織との関連が指摘されるのみ である7)。拙稿『北海道帝国大学および小榑高等商業学校侓外国人 教師官舎（大正14年〜昭和 2 年）について』8) で、北海道帝大の官 舎設計にたずさわった営緗課職員数名を概略紹介したが、組織の変 遷および構成員についての総合的な考察は別途報告することにして いた。また、北海道帝大の建築活動についても報告してきた ${ }^{9) か ゙ 、 ~}$
*北海道大学大学院工学研究科都市環境工学尃攻 助手・工修

** 北海道大学大学院工学研究科都市環境工学専攻 教授・工博

*** 北海道大学大学院工学研究科都市環境工学専攻 助教授・博士 (工学)
Research Assoc., Div, of Urban and Environmental Eng., Graduate School of Eng., Hokkaido Univ., M. Eng.

Prof., Div. of Urban and Environmental Eng., Graduate School of Eng., Hokkaido Univ., Dr. Eng.

Assoc. Prof., Div. of Urban and Environmental Eng., Graduate School of Eng., Hokkaido Univ., Dr. Eng. 
いずれも断片的、あるいは通史的なものであり、建築技術者につい ては、主に営絴課長を中心にふれたにすぎない。

そこで本稿では、主に北海道大学所藏の史料一総務部人事課所藏 『履歴簿』および、施設部企画課所蔵の $1 ， 500$ 葉をこえる設計図 面、経理部管財課所藏『北海道大学所属国有財産沿革』（全12 冊之 所管不明の図面および簿書を含んだ付録 2 冊の計 14 冊、以下『国有 財産沿革』と略）一をもとに、北海道帝大の営繥組織の沿革および 建築技術者の全貌を明らかにするとともに、官庁建築設計組織の一 つとしての北海道帝大営繥課の位置付けを試みるものである ${ }^{10) 。}$

『履歴簿』からは、技師、技手にとどまらず、これまでの帝大営 繕組織の研究ではほとんど顧みられることのなかった嘱託や雇など の建築設計への関与も読み取ることができる。さらに、北海道帝大 は学内に建築学科を持っていなかったため、建築設計顧問という建 築設計に対するイニシアチブを握るプロフェッサーアーキテクトが 存在していないという点で、他の帝大営縉組織とは様相を異にす る。設計体制を含めた営繒組織の全貌を明らかにするには、特に北 海道帝大においては嘱託や展も含めた建築技術者全体を対象に考察 を加える必要があろう。組織の沿革や技術員の特性を把握せずに、 具体的な建築事例を举げ、設計者や建築的特徵を諭じることは、か えって営縊組織の全貌を見えづらくする危惧があると考え、本稿で は営繒組織と建築技術者の全容を明らかにすることに努め、個々の 建築物の建築的特徵と、その設計者および設計体制の考察について は稿をあらためて報告することにしたい。

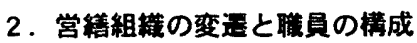

北海道帝大は、札幌農学校(明治 9 年創立)、東北帝大農科大学 (明 治40年改組)の時代を経て、大正 7 年 4 月に創立した。

大正 6 年度以前は、後述のように文部大臣官房建築課と別組織の 大学独自の営䋨機構はなく、また同建築課札幌出張所の職員につい ても不明な点が多いため、職員構成を把握することは現時点では困 難である。そこで本稿では、北海道帝大創立および営繕組織の設置 とも重なることから、大正 7 年度以降をとりあげた。また、昭和 16 年度以降は職員の出入りが激しく、かつ建築工事件数も激減する ${ }^{11)}$ ため、第二次大戦勃発以前の昭和15年度までを対象とした。

大正 7 年度以降の営縡職員数の推移を示したものが図ー 1 であ る。『北海道帝国大学職員録』から、昭和 2 年度以降の技師、技 手、嘱託㧍よび扈の氏名を確認できる。それ以前については、『北 海道帝国大学一覧』から、技師、技手および嘱託の氏名を知ること ができるのみで、㕍については各々の『履歴簿』に記述してある在

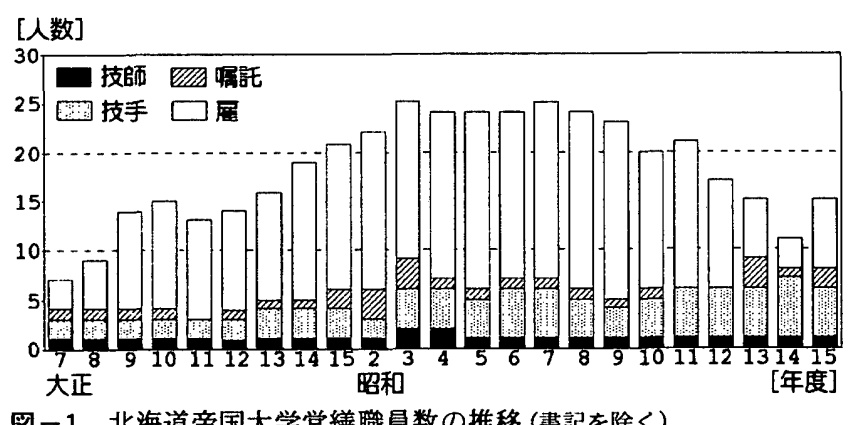

图一1 北海道帝国大学営繥職員数の推移 (書記を除く)
任期間から人数を算定した。なお、営䋨職員数に書記は含まない が、技術者については建築以外が専門の者も算入している。

図 -2 は大正 7 年度以降昭和 15 年度まで在職した営䋹職員のうち で、『履歴簿」より経歴が判明する主な建築技術者について、最終 学歴、在任期間、北海道帝大着任前の略歴について一覧にまとめた ものである。

ここでは大正 6 年以前をあわせて、昭和 15 年までの文部大臣官房 建策課と、北海道帝大 (前身含む) 営縖組織との関連および沿革を、 技師および呞託に着目して簡単にまとめておきたい。

\section{2-1 北海道帝国大学設立以前}

農学校時代法、北一条キャンパスの前期 (明治 9 年〜32年) と、北 八条キャンパスの後期（明治 32 年〜 40 年）に二分される。農学校の 管轄は、創立から明治 15 年 2 月までが開拓使、同年 3 月から 19 年 1 月までが農商務省 (北海道事業管理局扱)、同年 2 月から 28 年 3 月ま でが北海道庁、同年 4 月以降が文部省と変遷している。

校舎等の設計業務はその時々の管轄主体によって行なわれてい た。創立期の前期農学校の諸建築は開拓使工業局が担い、後期農学 校キャンパスは文部大臣官房建築掛札幌出張所 (以下札幌出張所) が 設計している。その主任技術者として安達喜幸（1827～1884）およ び中條精一郎が知られている。

札幌農学校の組織内に営繒事務機構は存在するものの、その中に 設計組織は置かれていなかった。明治 9 年の『職制』12)に見る「理 事、同28年『校務規程』12)の「会計部営縓掛、同32年『処務規 程』12)の「会計課」がそれに相当するが、その内容からは設計業務 の存在をうかがうことはできない。

明治 40 年、農科大学への改組、改称に伴い、明治44年 4 月 1 日に 「会計課」の中に「臨時建築係」が発足した。この時、文部大臣官 房建策課雇として札幌出張所に勤務していた安積久助（1881〜 1923）が農科大学より「会計課臨時建築係」㕍を命ぜられた。『履 歴簿』によると、その職務は「工事検查官吏」である。『国有財産 治革 付録』収録の簿書中に、建物台帳の作成に関する面積や価格 の算定、平面図の記録などに安積の署名および捺印が確認でき、主 な職務にはこれらが相当すると推察される。

明治 40 年 6 月から大正元年 12 月まで札幌出張所長であった新山平 四郎 ${ }^{13)}$ は、明治44年 4 月に農科大学より「臨時建築工事設計監督」 を啒託されているが、『履歴簿』の記載を見るかぎり、前述の「会 計課臨時建築係」への勤務は命ぜられていない。したがって、この 時期の「会計課臨時建築係」もまた農学校時代と同様、設計業務を 扱わない機構であったと推察される。もちろん「会計課臨時建築 係」勤務で設計業務を委嘱された建築技師の存在は確認できない。

新山の退職後、大正 6 年までの札幌出張所長不在期間 ${ }^{14)}$ を経て、 大正 6 年 9 月に浦五十吉 (1889 ? ) か、翌年の北海道帝大設立に 向けて、文部省より「札幌医科大学新設工事の設計」の嘱託を受 け、文部大臣官房建築課において執務する15)。大正 6 年 10 月には 栗山俊一 (1882〜?) が東北帝大技師に任官され農科大学勤務とな る。制度上は東北帝大所管だが、実際には農科大学専属の営結技師 として勤務していた。浦の嘱託、そして栗山の農科大学への着任 は、北海道帝大営緢組織設立への準備段階ととらえることができる であろう。 


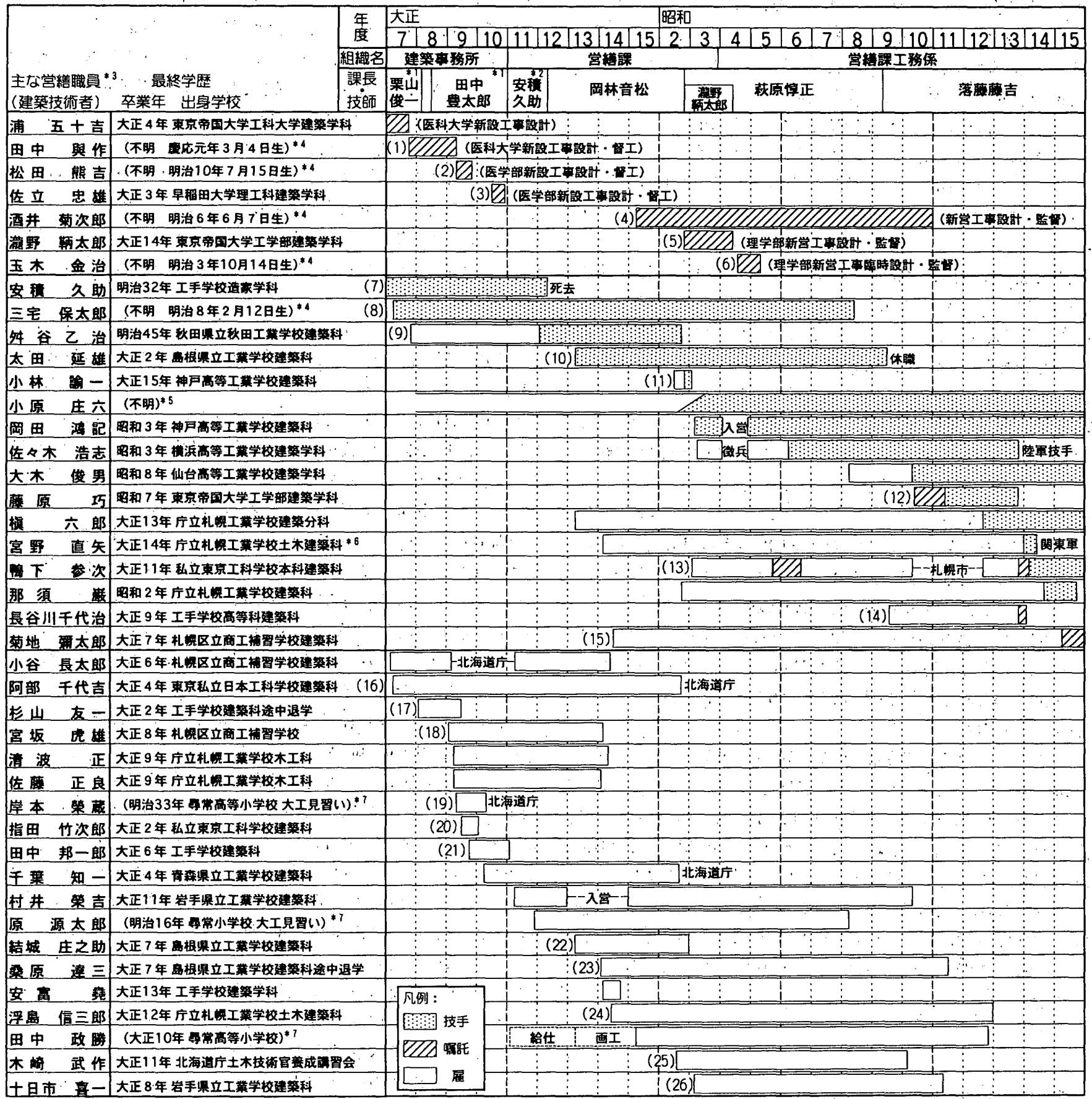

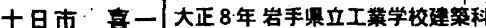

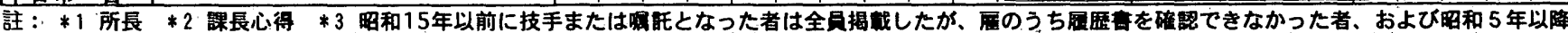

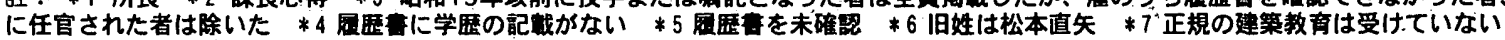

北海道帝大着任前の略歴：(1)明治28年4月～36年9月陸軍検疫所および埼玉県技手、大正元年8月～2年9月台湾総督府民生部土木局（2）明治39年 4 月新家孝正に

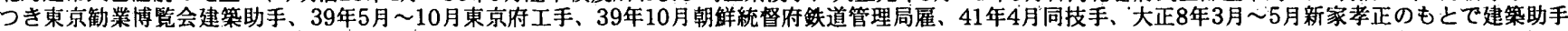
（3）大正 4 年 3 月 8月曾袢中條建筑事務所客員、4年8月～9年1月大倉土木侏）(4)明治33年3月北海道庁事業手、35年12月同技術員、41年6月同技手、大正13年12

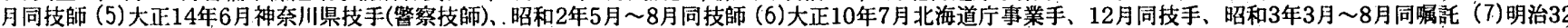
作5月～35年5月束京工業学校改策建築猢屋、35年7月～39年6月仙台市において土木請負業に従事、39年6月～40年1月私立東北中学校技手、明治40年3月文部

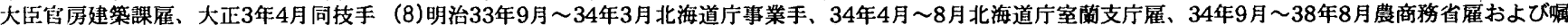

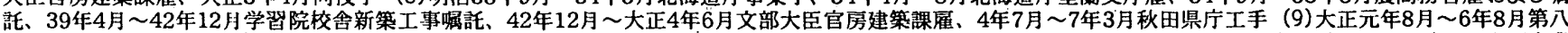

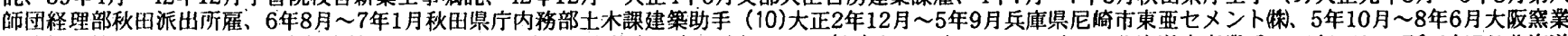

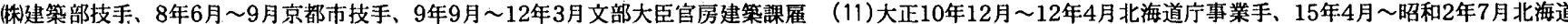
庁技手 (12)昭和7年4月～8年9月褔岡市長門組、昭和8年9月九州帝国大学嘱託 (13)大正12年1月～昭和 2 年5月東京市村瀬建筑事務所 (14)明治44年4月～大正3年

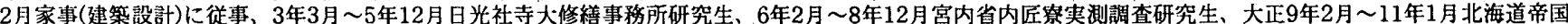
大学工学部教室および奇宿舎新築工事に従事、11年 2 月 12年2月小樽市石川建策事務所、以降小樽、東京、仙台などで建築事務所自営. (15)大正8年2月１0年

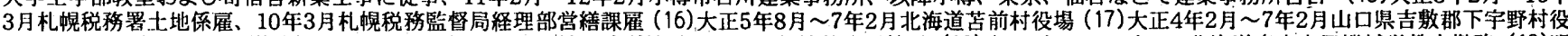

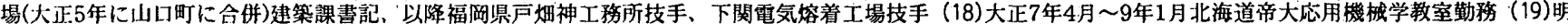

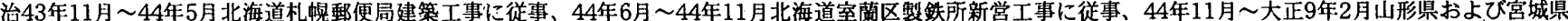

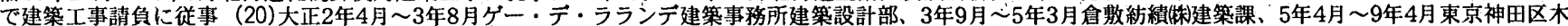

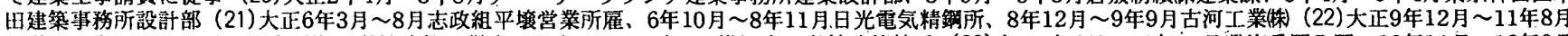

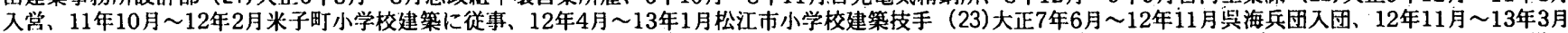
文部省建策課松江出張所図工，13年5月～8月島根県领石郡鍋山村尋常高等小学校建筑工事監督，13年9月～11月松江市㕍（24）大正12年4月小樽市役所営結浬 (25)大正10年12月北海道庁事業手、12年12月同技手 (26)大正8年3月～10年11月鉄道院(少)北海道鉄道管理局㕍、10年1月～昭和 2 年1月北海道庁技手

图一－北海道帝国大学営縡職員一覧 


\section{2-2 北海道帝国大学設立および営䌜課設置以後}

大正 7 年 4 月 1 日、東北帝大から分離独立し、北海道帝国大学が 設立された。同時に、後の「営繥課」の母体でもあり、かつ初めて の設計業務を担う組織である「建築事務所」（一般の建築事務所と の混同を避けるため、以下カキ括弧付きの「建案事務所」とした場 合、北海道帝大会計課建築事務所を指すことにする）が「会計課」 内に設置され、栗山がそのまま技師兼所長となった。栗山は翌 8 年 2 月に台湾総督府へ転出したため、同年 7 月に田中豊太郎（1870 〜?） が赴任するまでの 4 力月間は所長不在であった。栗山と田中 が所長を務めた「建策事務所」時代は、わずか 4 年の間に医学部 (もしくは医科大学) 新設工事設計の名目で、浦、田中與作（1865 〜?)、松田熊吉 (1877〜?)、佐立忠雄 (1886〜1957) の 4 名の焗 託が、任期を重複することなく代る代る委啒されている。

大正 11 年 1 月『北海道帝国大学処務規程」改正により「建築事務 所」は「会計課」から独立し「営繥課」へと組織変更された ${ }^{16) 。 と ~}$ ころが時を同じく、当時日本赤十字社北海道支部建設顧問を嘱託さ れていた田中は旭川での同病院設計のため退職 17) し、「営䌟課」の 設置当初は課長が不在となっていた。そのため安積が課長心得を務 めていたが、その安積も急病により大正12年 4 月 27 日に逝去する。 同年 5 月に文部技師岡林音松 (1885〜?) が、ようやく初代課長と して就任した。岡林は北海道帝大設立のための当初新設予定であっ た工学部、医学部および附属医院の工事がほぼ完了した昭和 2 年 9 月をもって退任し、䌇いて理学部の開学に向け昭和 2 年 6 月より焗 託を受けていた北海道庁技師萩原惊正 (1892〜 ?) が営繒課長に着 任することになる。

営䜌職員数も大正 11 年度より徐々に増加し、昭和 3 年度には設立 当初から倍增の 25 名を数える（但し事務員は含まない）。昭和 3 年 12 月には「営繥課」が「事務係」と「工務係」に分割された ${ }^{18) 。 ~}$ 萩原の在任中には、瀧野䩡太郎（1902～?）が理学部新営工事設計 のため技師兼啒託として委啒された。北海道帝大営䌜課で唯一技師 が複数名在籍した期間である。昭和 9 年 5 月には病気退職した萩原 の後を受け、落藤藤吉（1901～1959）が着任する。戦時体制への突 入とともに、建築工事件数が減少し、それに伴い営縡課人員も主に 雇が削減されていった。

\section{3. 主な営籍技術者}

ここでは、北海道大学人事課所蔵『履歴簿』を基礎史料に、技師 をはじめとして、北海道帝大キャンパス施設の設計および計画に関 与したと考えられる主要な営緗技術者の履歴を紹介し、北海道帝大 営縒組織内での役割について考察する。

\section{3-1 技師}

栗山俊二 一明治 42 年 7 月東京帝大工科大学卒業。明治 43 年 1 月か ら名古屋高等工業学校建築科講師を勤め、同44年 1 月に教授となっ た。担当科目は「一般構造」 ${ }^{19)}$ 。名古屋高等工業学校在任中、朝鮮 総督府の啒託を受け、朝鮮において古䠖調査を数度行なう。

大正 6 年 10 月東北帝大農科大学に勤務、「医科大学新営費所属物 品会計官吏」および「医科大学新営工事検査官吏」を任命され、同 7 年 4 月の北海道帝大への昇格にともない同建築事務所長を命ぜら
れた。大正 8 年 2 月、台湾総督府技師に転任している。

田中豊太郎 - 明治23年 2 月工手学校造家学科卒業。卒業後值ち に陸軍省図工となり、28年 9 月に陸軍技手、29年 4 月に臨時陸軍建 築部技手となる。37年 8 月には大葴省䠛時煙草製造淮備局に転じ、 三橋四郎のもとで技手として働く。38年10月に大蔵省臨時建築部技 手となり、その間に『和洋建築工事仕様設計実例』20)を著わしてい る。明治 41 年から大正 2 年までの間、公務の余暇に神田の私立東京 工科学校建案科で講師を勤めた。大正 3 年 5 月から一時期、倉影紡 績に勤務。大正 6 年 9 月には文部省建築課に移り、大阪高等工業学 校校舎新築設計にたずさわり、翌 7 年 4 月には同省建築課大阪出張 所長心得となる。

大正 8 年 6 月、北海道帝大より「工学部創設工事ノ設計及監督」 を受け同建築事務所長となる。同 8 年10月には大臣官房建案課札幌 出張所長心得を併任する ${ }^{21)}$ 。前述のように、大正11年 1 月に日本赤 十字社旭川病院建設のため退職し、その後は札幌で建築事務所を自 営した。大正14年に『建築仕様全集』 ${ }^{22)}$ を出版。昭和4年より、長 野宇平治に請われ、日本銀行第一期增築工事の現場監督を勤めた が、その後体調を崩し、第二期工事の半端で辞職した ${ }^{23) 。 ~}$

岡林音松 一明治 41 年 7 月名古屋高等工業学校建築科卒業後、た だちに帝国鉄道庁（後の鉄道院）㞕となり、43年7月技手となった。 大正 4 年 3 月には島根県技手、同 8 年 12 月には同技師を勤め、その 間大正 6 年から松江市母衣商工業補習学校および白渴商工業補習学 校の訓導を兼任している。大正 9 年 8 月から文部技師となり大臣官 房建策課松江出張所長兼鳥取出張所長を勤めた。

大正 12 年 5 月、北海道帝大に営緢課長兼技師として就任。同 13 年 4 月から土木専門部講師を嘱託、同年12月から文部大臣官房建築課 札幌出張所長を兼任した。医学部附属医院（主要病棟は大正12年〜 昭和 2 年に竣工）と工学部本館（大正12年12月 6 日）の建設工事中 に在任しているが、『履歴䤃』には「会計官吏」や「検査官吏」な どの拝命があるのみで、設計業務に関与した記述は見られない。

辇原惊正 - 明治44年 7 月関西商工学校建築学科卒業後、河合建 筑事務所 ${ }^{24)}$ を経て、大正 6 年11月より大蔵省踟時建築課に勤務、大 阪税関庁舎新築工事設計を行なう ${ }^{25)}$ 。大正 9 年 9 月文部大臣官房建 勧課神戸出張所長心得となり、神戸高等商船学校創立工事設計およ び監督を、同 12 年 4 月からは姬路出張所長心得となり、第二四高等 学校創立工事設計および現場監督を担当した。

大正 12 年 8 月北海道庁土木部建築課に建築技師として着任、昭和 2 年 6 月には北海道帝大より「新営工事二関スル設計及監督」の嘱 託を受けた。同年 8 月に北海道帝大技師、9 月に同営絴課長となっ ている。昭和 3 年 4 月に「理学部創設二関スル工事設計及監督」を 拝命、学内初の本格的 R C 造である理学部本館の設計を手掛けた。

落藤藤吉一大正14年 3 月東京帝大工学部建築学科卒業。同年 4 月 大阪府警察技師、昭和 3 年 11 月に大阪府建築技師となる。昭和 9 年 5 月より北海道帝大営絴課長を勤めた。戦後、改組により文部大臣 官房教育施設部札幌工事事務所長兼北海道大学事務局施設課長に就 任、昭和 25 年からは 2 年前に新設された北海道大学工学部建築工学 科建築計画学第一講座教授も併任した。

\section{3-2 嘱託}

栗山と田中が所長を勤めた「建築事務所」時代に在籍した 4 名の 
表-1．佐立忠雄の大倉土木勤務時代の関与作品

大畣喜八郎葵町本邱模梾替厂事製図 (助手)

東京製網会社大岛町製網所全部新築工事設計並製図

日本化学工業会社会津電解工場新筑工事設計並製図

同会社取粒役加瀨忠次郎鎌合別邱新筑工事設計（主任)並現場監督

東京製綱会社月島工場災害復旧工事設計並彆図（工学士板部保治*と共同）

日本化学工業会社龟户工場染料部新築工事設計並製図(

同郡山工場全部新築工事設計详製図 (")

東京製網会社社長山时昌邦邱洋館新築工事設計主任及製図

医学博与吉井直三郎邱模様替工事設計主任並現場監栶

相模紡續会社取楴役牧山熊二郎平塚別邱設計主任

大會喜八郎小田原別新新築工事設計 (伊東忠太監督)

牧山能二郎高田馬場本邸新策工事設計主任

那山大日本紡績会社工場設計主任

喜谷市郎右衛門**橴谷本昉設計主任

加濑忠次郎目黒別邱新策工事設計主任

山本俤二郎***洋館設計（独适人建築家ワセランの原作に基つくく）

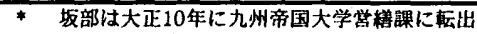

**この当時は帝国ホテル取媂役

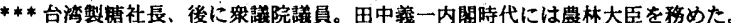
自新は上目煮 (覨在の目黑区役所の一帯)にあった。'孫の山本加寿子氏による) ワセランという名前のドイツ人建築家については不明。

嘱託は、先にも述べたように、いずれも医学部新築工事の設計を委 嘱されている。

浦五十吉は大正 4 年東京帝大建築学科を卒業し、大正 6 年 9 月に 北海道帝大より「札幌医科大学新案工事設計」の嘱託を受けてい る。次に入れ替わるように着任した田中與作と松田能吉は、ともに 『履歴簿』には学歴の記載がないため、正規の建築教育を修学して いないことが想像できる。田中與作は明治28年から同36年まで陸軍 検疫所および埼玉県技手、大正初年には台湾総督府民生部土木局に

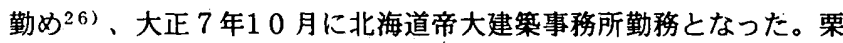
山の退職後、田中豊太郎が着任するまでの 4 力月間、建築事務所長 代理を勤めている。松田は新家孝正 ${ }^{27)}$ の元で東京勧業博覧会の建築 助手を勤めた後、東京府工手、朝鮮総督府鉄道管理局屈、技手を歴 任した。その後、長野県郷田建築事務所、長野市松田工務店に勤務 し、建築を現場において学んでいる。北海道大学着任直前にも再ひ 新家に就いて建築を学んでいた。佐立忠雄は佐立七次郎の長男で、 大正 3 年に早稲田大学を卒業（2 期生）している。卒業間もない大 正 4 年 3 月から曾禈中條建築事務所に客員として入所し、曾神達蔵 に就き建築設計に関する実地指遒を受けた。同年 8 月には片山東熊 の紹介により大倉土木組に入社している。大倉土木在職中に関与 した建築設計業務は多数あり、『履歴簿』の記載内容を表-1に示し た。大正 10 年 6 月北海道帝大より「「医学部新築工事ノ設計並督工j

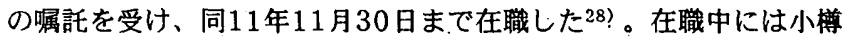
市に現存する「和光在」(大正11 年竣工)の設計を行なっている。

瀧野䩡太郎は大正 14 年東京帝大建築学科の卒業で、同年から神奈 川県技手および技師を勤めた後、昭和 2 年 11 月北海道帝大より「理 学部新営工事二関スル設計及監督」を嘱託さ抗た。同年12月には北 海道帝大技師、同 3 年12月には文部技師となっている。

酒井菊次郎 ${ }^{29)}$ (1873〜?) と玉木金治 $(1870 ？$ ）の 2 名は、北海 道帝大着任前は北海道庁の技師および技手であった。酒井は特に学 部の指定はなく「新営工事二関スル設計及監督」を、玉木は「理学 部新営工事二関スル臨時設計及監督」を嘱託されている。両者とも 設計の名目で委嘱されているが、酒井はその後、営絴課長出張不在 中事務代理〕、医学部建築事務〕、営緗課長事務」の命を受けてお
り、もっぱら事務取扱を担当していたと考えられる。一方の玉木は 道庁時代には治水事務所に勤務しており、土木系の技術職であった ことがうかがわれる。

\section{3-3 その他おもな営緗技術者}

ここでは技手および屈のうち、特に重要と思われる技術者の略歴 についてふれておきたい。”

安積久助一明治 32 年工手学校造家学科卒業。卒業後 3 年間は文 部省総務局建築課扈として東京工業学校改築工事にたずさわり、そ の後仙台に移り土木請負業に従事、明治 39 年 3 月から翌年 1 月まで 私立東北中学校の臨時建築技手を勤めた。明治 40 年 3 月に文部大臣 官房建築課雇となり、同年 7 月に東北帝大創立事務取扱として札幌 出張所勤務となった。以後の履歴は前述の通りである。

指田竹次郎 (1891〜?) 一明治42年東京高等工業学校附属工業補 習学校建築科を卒業後、2 年間東京の工務店に勤務。明治 45 年 3 月 に東京工科学校建築科へ入学し、大正 2 年 3 月に卒業した。卒業後 直ちにゲー・デ・ラランテ建築事務所に入所、建築設計部勤務とな る。しかし、入所わずか 1 年余後の大正 3 年 8 月、テ・ラランテの 死去にともない同事務所を辞職、同年 9 月より倉教紡績建築科へ転 じる。大正 5 年 3 月に同社を退職し、同年 4 月から東京神田の木田 建築事務所へ就職した。大正 9 年 6 月北海道帝大雇となり「医学部 新設工事係」を命ぜられる。この時点での月俸が65円。同年 8 月に は108円、12月には120円となっている。ちなみに、指田と同様、 東京の私立工業学校卒で屈の阿部千代吉は55円 (大正 9 年 8 月)，県 立工業学校卒の雇㱜谷乙治が78円 (同)、文部大臣官房建築課から技 手として着任した三宅保太郎が108円 (同)、同じく技手の安積久助 が123円 (同)であうたことを考えると、㕍とはいえ、給与面では技 手レベルの待遇を受けていたことがわかる。大正10年 2 月末に依願 解㕍となっている。

曻谷乙治 (1893〜 ?) 一明治45年秋田県立秋田工業学校建築科を 卒業。第八師団経理部秋田派出所扈、秋田県庁内㢦部土木課建築助 手を経て、大正 7 年11月北海道帝大㕍、同12年に技手となる。

太田延雄（1896〜？）－大正 2 年島根県立工業学校建築科を卒 業。兵庫県尼崎市東亚セメント、大阪筧業建築部技手、京都市技手. などを経て、大正 9 年 9 月より文部大臣官房建筑課虽となる。鳥取 出張所へ赴き、大正11年からは鳥取商工尃修学校講師を委啒、同 12 年 3 月末日をもって御用済みにより解雇。その後、東京市で民間建 箱工事にたずさわり、大正 13 年 3 月北海道帝大技手、営䌜課勤務と なる。在職中、公務の傍ら医学部教授有馬英二邸（昭和 3 年竣工）之 同内村祐之邱（昭和 5 年竣工）を設計している。

岡田鴻記 (1907 1981) 一昭和 3 年神戸高等工業学校建築科卒業 後ただちに北海道帝大技手となる。公務の余昵に萩原㥉正とともに 理学部助教授 (当時、後に北海道大学学長) 杉野目晴貞䄮 (昭和 8 年 竣工、登録有形文化財)を設計している。戦時中满州（現中国東北地 方）に赴き、終戦後1950年から札幌で設計事務所を自営した。'

\section{4. むすひー 北海道帝大営繙課の設計体制 一}

文部省営繒から独立以降の帝国大学営繥組織の活動の一事例とし て、北海道帝大営縓課の沿革および主な職員の履歴について述べて 
きた。ここでは、各人の履歴を検討、整理することにより、北海道 帝大営繒課の組織体制に考察を加え、むすびとしたい。

北海道帝大営縓課は、営繥課長と文部大臣官房建築課札幌出張所 長兼任の技師が 1 名（瀧野の在任期間のみ 2 名）、設計および督工の 嘱託が 1 名、技手が 2 ～名という体制が常時ほほ変わることな く、必要に応じて雇を加え、設計活動を行なっていた。北海道帝国 大学官制第 5 条ノ 4 に技手八専任五人判任卜ス、上官ノ命 3 承ケ 技術二従事ス」 ${ }^{30)}$ とあるが、実際に専任の技手が 5 人を数えたのは 昭和 14 年度のみである。不足している技手を補つたのは、新設工事 設計を機にその時々に呼ばれた嘱託で、彼らがある種、専任技手の かわりとして、あるいは、それ以上の働きをしたと考えてよいであ ろう。

技師に限ってみるならば、栗山に始まり萩原にいたるまで全員が 文部省札幌出張所長との兼任であり、形式的には落藤の時代になっ て初めて文部省中央からの独立が計られたように映る。しかし、現 実には中條や新山が文部省本省からの出向であった ${ }^{31)}$ のに対し、栗 山以降の技師はすべて地方の出張所からの転任であった。このこと は、文部大臣官房建築課の組織自体が「大学令」および「高等学校 令」にともなって巨大化したことの顕われでもあるが、翻せば各地 方の出張所機能が充実し、本省からの独立が図られたことの裏づけ にもなる。さらに北海道帝大では独自の営繥組織を持ち、そこの所 員を充実することにより、キャンパス内の諸施設の建設を行なって きた。建築一件書類中 ${ }^{32)}$ に文部省との往復文書を確認することがで きるが、その文面はあくまで文部省への報告であり、実質的な決定 権は北海道帝大営繒にあったことがうかがわれる。

設計業務だけでなく人員の募集も北海道帝大自体で、更にいうな ら課長 (もしくは所長) の自由裁量が認められていた。田中豊太郎が 建築事務所長を勤めていた時代に、その傾向を顕著に見ることがで きる。大正 9 年 6 月に雇として勤務した指田竹次郎は、田中が教鞭 をとっていた時代の東京工科学校の卒業生であり、さらに北海道帝 大勤務前には田中と同じ倉敖紡績に勤務している。田中の伝で北海 道帝大へ着任したことが容易に想像できよう。また田中は、松田の 退職から佐立の着任までの啒託の不在期間に、地元札幌の技術者を 集中的に採用している。指田が呼び寄せられたのも、まさにこの時 期にあたる。その後の採用人員も、過半は地元札幌で官庁営絴もし くは建設業についていた者である。営䌜課への改組以後、岡林の時 代になると、地元技術者の採用傾向はより一層顕著になる。このよ うに営綁スタッフ採用の自由度といった点からも文部省中央からの 独立傾向を裏付けることができる。

最後に営縡職員の経歴についてまとめておきたい。宮本は前掲論 文中で、大正期以降の「帝国大学の技師はいずれも東京帝国大学建 築学科の卒業生にて占められ」と考察しているが、本稿で述べてき たように東京帝大卒の建筑技術者は技師 4 名、啒託 2 名（うち 1 名 はまもなく技手) を数えるのみである。中央との関連を東京帝大卒 という学歴で表わそうとしたと考えられるが、筆者らは、その傾向 を文部省勤務との関連から考察したい。「建築事務所」時代の技師 および技手はすべて文部省勤務の経歴を持つ。その反面、嘱託の 4 名および給与では技手レベルの待遇を受けていた指田には文部省勤 務の経歴がない。つまり「建築事務所」時代には人員の採用に関し ては自由度が与えられていても、現実的な任官になると文部省勤務
の経歴があるものは技師および技手にはなりえるが、ないものはあ くまで啒託か㕍としてしか勤務できなかったといえ、制度上の待遇 の違いを月俸の額で埋め合わせていたことが推察できる。大正 11 年 の営繥課設立以後は、文部省勤務経験のない舛谷がまず技手に登用 されることに始まり、さらに落藤の時代には地元札幌出身の大木、 槙、宮野、那須などの雇が技手に昇格し、文部省中央指導型の任官 は完全に払拭される。

また、『履歴簿」に学歴の記載のないものが若干名いるため確定 的なことはいえないが、高等工業学校 (もしくは工手学校) 以上の高 等教育を受けた者が、技師を含め技手および啒託として業務をこな し、雇は大半が工業学校卒で占められている傾向がみられる。雇員 のうち地元札幌の出身者は半数を数える。札㨪における建筑教育は 大正 $6 \sim 8$ 年の札幌区立商工補習学校に始まっており、北海道帝大 の営繒組織の設立と合致していることがわかる。

以上、本稿では北海道帝大の営綧組織を対象に、一帝大営繕組織 の文部省中央からの独立化の進行の具体的内容を考察してきた。

「建築事務所」時代には任官の面において文部省中央指導型の一面 があったことは否定できないが、「大学命」および「高等学校令」 が契機となって、キャンパス施設というハード面の整備がなされ、 さらに高等教育機関の充実にともなう建築技術者の養成が相まっ て、北海道帝大の営䋨組織が独自の活動を行なうようになったとい うことができるであろう。

[註記]

1）九州大学出版会、1989年。

2）まず、明治 40 年6月 21 日に東京帝大と京都帝大に営繜課ならびに建筑部 が扔かれ、同 45 年 3 月 31 日に東北・九州の雨帝大に建築掛と営縍課が設 けられた。

3）京都大学工学部建築史研究室編『京都大学建築八十年のあゆみ一京都大 学構内歴史的建造物調查報告』(京都大学庶務部広報調查課刊, 1977年)

4）西村公宏『東北帝国大学医学部の外構について』（日本建築学会東北支 部研究報告集第59号, 1996年6月）および、片野博『福岡県における国の 地方機関活動実態とその問題点, 明治・大正・昭和 建築活動の地方性 に䦎する研究』(日本建筑学会計画系論文集 第464号, 1994年10月)など がある。

5）技師として栗山俊一、萩原惊正、落藤滕吉の 3 名の名前を紹介している のみである。

6）文教ニュース社，1983年。

7）例えば、廣田基彦『開拓使・道庁営䋹80年の覚書き』(私家版、1997年 10 月)、小坂映王ほか『昭和初期における小樽市の営綪事業について』 (日本建管学会北海道支部研究報告集No.63，1990年3月）、安藤理美ほか 『札幌市の大正・昭和初期営綪組織について』（日本建築学会北海道支部 研究報告集No.69, 1996年3月)がある。

8）日本建筑学会計画系論文集 第484号，1996年6月。

9）例えば、越野「札晩農学校、北大の建勧」(『北海道の開拓と建筑 上巻 一解説・写真』，1987年)、江下友三枝ほか『北海道帝大創立期の医学部 および同附属医院の建築について』（日本建筑学会北海道支部研究報告集 No.69,1996年3月)、山後正憲ほか『後期札幌農学校のキャンパスの建 築に関する史的研究』(日本建筑学会北海道支部研究報告集No.71, 1998 年3 月)、啮谷誉人ほか『後期札幌農学校・東北帝国大学農科大学におけ る建築活動』（日本建筑学会北海道支部研究報告集No.72，1999年3月）が ある。

10）本稿は、江下、越野、角、池上『大正・昭和初期における北海道帝国大 学の営繥組機について』（日本建筑学会大会学術講演梗概集(近畿), 1996 年9月)で発表したものに大幅に加筆・修正を加え、再構成したものであ る。

11）昭和16年12月に低温科学研究所が竣工しているが、これは海軍省の委託 による。

12）これら溥書は、すへて北海道大学附属図書館北方資料室所蔵。

13）明治35 年6月から札幌出張所長心得を任官されている。また、宮本は前 
揭書で、新山が明治 42 年12月ころに札幌出張所長から秋田出張所長に転 じたと指摘しているが、『履歴簿』の記述によると、あくまで札帽出張 所長のまま、明治 42 年 12 月から秋田出張所長、明治 43 年 4 月から小樽出 張所長を兼任したことが読み取れる。

14）北大施設部企画課所蔵の農科大学時代の建筑一件書類によると、新山退 睵の翌大正 2 年の工事仕様書には安積の捺印および訂正印が見られる が、大正 3 年以降の仕様書には工事請負人大星三松および大星鶴松の择 印・訂正印がある。この期間は、建築工事だけでなく、設計も外部発注 であったことが想像される。

15）『履歷簿』には具体的な勤務地の記载がないため、東京の文部省本省勤 務か、札幌の建築出張所勤務かの判断はつかない。文部省のみに勤務の 場合は、例えば中條精一郎がそうであるように、北海道大学には『履歴 簿』が保管されない。浦は『履歷簿』の記述だけから判断すると、文部 省勤務のように受け取れるが、北海道大学に『鼠歴簿』が保管されてい ること、大正7年度の建築関連溥書 (北海道大学施設部企画課所蔵) に建 築事務所勤務として名前が確認できることから、なんらかの形で北海道 帝大より建策事務所勤務を啒託されていたと推察できる。

16）大正11年1月1日付制定「北海道帝国大学処務規定」の条文には営結課の 庶務内容が以下のように記されている。

「第九条 営絴課二於テハ左ノ事務ヨ掌ル。

一. 建築物ノ诌計及工事ニ関スル事項

二建筑物ノ修緒二関スル事項

三煖房給水瓦斯電気及椧藏装蝐ノ新設又八修䋨二関スル事項

四 器具機栊類ノ設計並製図二関スル事項

五 工事請負及物件供給二関スル事項

六 物品会計二関スル事項」

大正旰には「土木工事ノ設計並二施工二関スル事項」が追加された。

17）大正 11 年 5 月 11 日に日本赤十字社北海道支部より啒託を受けている。旭 川病院は大正12年12月に竣工した。 RC造2階建て。

18）工務係の業務は、噇15）記載の項目のうち一、三、五、六および大正 13
作の追加事項が該当し、さらに「建築材料其他諸般ノ調查二関スル事項】 が追加された。また昭和稏脏に庶務規定が改正になり、「土木、建築、 同附属工作物、同付帯設備並二仮設物二対スル新設、堌、改、移策修繥等 ノ場合審查二関スル事項」が追加された。

19）日本建築学会編『近代日本建築学発達史』（丸善，1972年）による。

20）建築書院発行、1905年。上下卷。辰野金吾および妻本頼黄による序文が あり、三橋四郎が校閱。

21）後述するように、田中は文部大臣官房建築課札幙出張所長心得を併任す る。『建筑雑誌』大正 9 年 7 月号に、田中の紹介による、札覞在住で「文 部省建築課出張所」、勤務の准員福山祭記という人物が記載されている。 福山の『履歴海』は北海道大学には保管されていないので、北海道帝大 建築事務所には関係のない、文部省管轄の技術員であると想像できる。

22）建策書院発行，1925年。矢橋堅吉の校閲。また1929年には工業書院よ り『建筑見棈便覧』を著している。

23）『日本建筑士』第 22 卷 4 号（昭和 13 年 4 月）揭載の「長野宇平治君追悼の 座談会 (於長野㿟)」の記述による(駒木定正博士の御教示による)。

24）当時の関西商工学校建筑学科救務主理は河合浩藏であった。この河合建 築事務所は、大阪の河合浩藏の建築事務所と考えられる。

25）『建築雑誌』(大正9年8月)・の巻末に大阪税関汀舎が紹介されており・設 計監督大藏省、担当技術者菻原惊正」とある。

26）途中の瞕歴不明。『履杯簿」に記載がない。

27） $1857-1922$ 。明治15年工部大学校造家学科卒業。工部省技手。

28）估立忠雄の侽・佐汒一郎氏(栃木県小山市在住)によると「北海道帝大勤 務時代には祭かなにかの設計をしたらしい」と伝わっている。

29）父は北海道庁旧庁舎の設計および監督に従事した北海道庁技術官・酒井 㢣次郎 (柱次郎) である。㐘次郎も喜一郎の別名を持つ。

30）『北大百年史通史』p.993

31）嵒本雅明『日本の大学キャンパス成立史』（九州大学出版会、1989年）参 照。

32）北海道大学施設部企画課所藏。 